\title{
Quality of Using Google Classroom to Support the Learning Processes in the Automation and Programming Course
}

\author{
https://doi.org/10.3991/ijet.v16i06.18847 \\ Maysa Abuzant, Monji Ghanem, Ayshi Abd-Rabo, Wajeeh Daher ${ }^{(凶)}$ \\ An-Najah National University, Nablus, Palestine \\ daherwajeeh@gmail.com
}

\begin{abstract}
Virtual and blended learning are suggested as means to support students' learning of the subject matter. The present study sought to examine how one educational tool for the classroom; specifically, Google Classroom, was used by a teacher of automation and programming course in the secondary school. One secondary school teacher and her two students participated in the research. The data collection tools were interviews of two types: asking the participants semi-structured questions, and requesting the teacher to show how she used the Google Classroom options to engage her students in online learning. The transcribed interviews were analyzed using thematic analysis depending on the model of Information Systems Success by DeLone and McLean.

The research results indicated that Google Classroom contributed to the quality of the learning of the students, which affected positively the teacher's and students' satisfaction and intention to use this educational tool in the automation and programming class. The participants pointed at the benefits of using Google Classroom, which once again influenced positively the participants' satisfaction and intention to use it for teaching and learning. The present study showed how a virtual classroom could be utilized in technology courses. The described phenomenon could give insights, not only to technology teachers but to the teachers of other disciplines, how to utilize virtual and information systems in their teaching in order to enrich students' learning.
\end{abstract}

Keywords - Google classroom, automation and programming, learning processes, secondary school

\section{Introduction}

Today's learners are accustomed to the convenience and flexibility offered by current technologies in their day-to-say life that they expect to find the same levels of anytime anywhere mantra in their learning process [1]. To address that issue, educators can resolve to using technological tools [2], including blended learning, which is, according to Throne [3], tailored to fit learners' needs. Blended learning combines online and face-to-face learning. Moreover, a definition of blended learning should include context, theory, method and technology [4]. 
Boelens, Van Laer, De Wever, and Elen [5] define blended learning as "learning that happens in an instructional context which is characterized by a deliberate combination of online and classroom-based interventions to instigate and support learning" (p.5). Thus in the online element and the classroom instruction, a blended learning should complement and support each other; where the online context is not just a mere add-on to classroom instruction [6].

Online and face to face interactions both have their distinctive features that when combined could elevate the learning experience [1]. Studies revealed that face to face interaction yields better outcomes when it comes to student performance as it relates to applying course concepts, however, student satisfaction, motivation and participation are higher in online classes [7]. Blended learning focuses on maximizing the attainment of the intended learning outcomes by adopting the "right" learning technologies to match the "right" learning to the "right" person at the "right" time [8]. This maximizing of the attainment occurs when the facilitator develops a transformative environment where complex learning skills could be developed [9].

Research provides clear evidence that blended learning has a positive impact on the teaching and learning process. Blended learning results in higher rates of attendance in face-to-face classes [10], as well as higher rates of student engagement [11] and interaction among learners [12]. This is especially true in the case of project-based blended learning where this learning can effectively improve students' abilities of selflearning, practical application and innovation [13]. Wang [14] found that blending learning has significant effect on improving teaching effect of Digital Art. Zhang et al. [15] found that blended learning affects positively students' learning by lengthening extracurricular learning time, enhancing students' learning interest, and increasing the opportunity of student-teacher exchange.

\section{$2 \quad$ Literature Review}

\subsection{Google classroom}

Recently much attention has been drawn to the use of Google Classroom in educational contexts. Research revealed that students perceive Google Classroom as a collaborative tool that helps them to stay in contact with their teachers and receive realtime updates [16]. Moreover, studies exploring the effectiveness of using Google Classroom in Blended learning contexts have indicated that the ease-of-use and not being time-bound features are what made Google Classroom blends so smoothly with face-to-face classes [17].

Albashtawi and AlBataineh [18] reported that Diploma Students had positive attitudes toward using Google Classroom in terms of its ease of use, usefulness, and accessibility. Heggart and Yoo [19] reported that Google Classroom increased student participation and improved classroom dynamics. However, Abid Azhar and Iqbal [20] reported that due to the lack of user-friendly interface teachers viewed Google Classroom as merely a basic classroom management tool helping them with file documentation. 
Kopeyev et al. [21] say that experimental studies confirm students' increased interest in Google classroom, where they have active roles.

\subsection{Theoretical framework: Model of information systems success}

To ensure that blended learning affects learning and teaching positively, the online component of the course needs to be effective and appropriate. Different frameworks were suggested in the literature to evaluate e-learning systems, where one of them is the Model of Information Systems Success (ISS) [22], where the present research adopts the last model. Since the model was proposed by Delone and Mclean [22] in their original article in 1992, it has generated a broad response in the literature [2324]; so, it has proven its validity in assessing the success of eLearning systems.

The ISS success Model (Figure 1) is an evaluation tool for the effectiveness of Information Systems (IS) success. It comprises six interrelated dimensions of success factors: system quality, information quality, service quality, Use/intention to (use), and net benefits. This Model proposed that the quality dimensions - system, information and service quality - of the IS have an impact on the users' satisfaction with the IS and the intention to use, i.e., how the user is using the system or intending to use it. As a result of this "use", several net benefits will be achieved. Consequently, the attained net benefits will go back to affect the user's satisfaction with the system or the continued use.

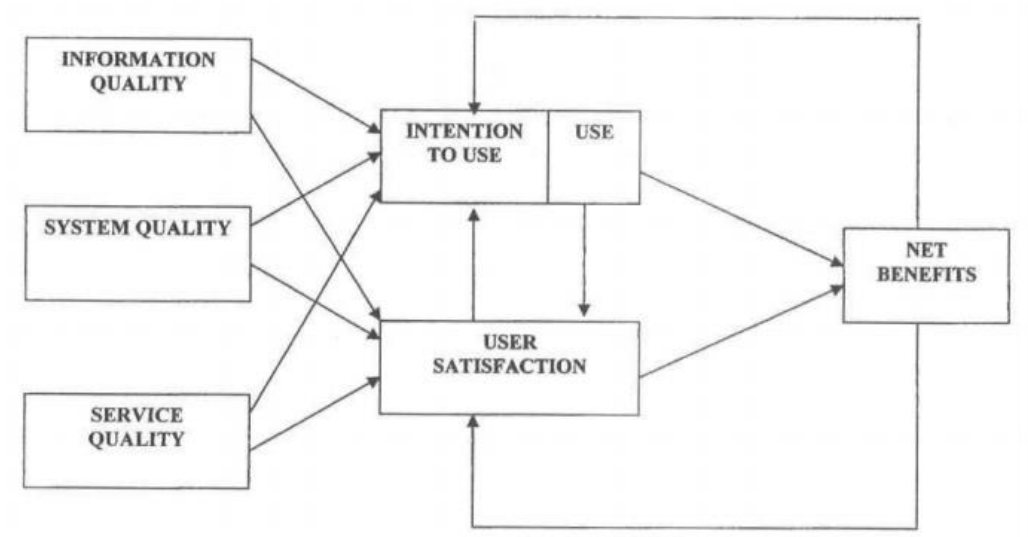

Fig. 1. A Model of Information Systems Success. Adopted from Delone and Mclean (2003)

The 6 dimensions are illustrated below (Table 1) as they were described by Delone and Mclean [25]. However, it is important to note that in this publication they suggested replacing the term "net benefits" with "net impact" as the later encompasses both the positive and negative outcomes of eLearning systems. 
Table 1. DeLone and McLean Model of Information Systems Success descriptors. Adopted form Delone and Mclean (2016)

\begin{tabular}{|c|c|}
\hline System Quality & $\begin{array}{l}\text { The desirable characteristics of an information system. For example, ease } \\
\text { of use, system flexibility, system reliability, and ease of learning, as well } \\
\text { as system features of intuitiveness, sophistication, flexibility, and re- } \\
\text { sponse times. }\end{array}$ \\
\hline Information Quality & $\begin{array}{l}\text { The desirable characteristics of the system outputs; i.e., management } \\
\text { reports and Web pages. For example, relevance, understandability, accu- } \\
\text { racy, conciseness, completeness, understandability, currency, timeliness, } \\
\text { and usability. }\end{array}$ \\
\hline Service Quality & $\begin{array}{l}\text { The quality of the support that system users receive from the information } \\
\text { systems organization and IT support personnel. For example, responsive- } \\
\text { ness, accuracy, reliability, technical competence, and empathy of the IT } \\
\text { personnel staff. }\end{array}$ \\
\hline Use & $\begin{array}{l}\text { The degree and manner in which employees and customers utilize the } \\
\text { capabilities of an information system. For example, amount of use, } \\
\text { frequency of use, nature of use, appropriateness of use, extent of use, and } \\
\text { purpose of use. }\end{array}$ \\
\hline User Satisfaction & Users' level of satisfaction with reports, Web sites, and support services. \\
\hline Net Impacts (Net Benefits) & $\begin{array}{l}\text { The extent to which information systems are contributing (or not contrib- } \\
\text { uting) to the success of individuals, groups, organizations, industries, and } \\
\text { nations. For example: improved decision-making, improved productivity, } \\
\text { cost reductions, better retention. }\end{array}$ \\
\hline
\end{tabular}

At the system level, accessibility, usability, awareness of user expectations, and learning ease were ranked of high importance to the success of the eLearning system. Lwoga [26] examined the factors that predict students' continual usage intention of web-based learning content management systems through employing a modified IS Success model with an added "instructor quality" construct. The results indicated that system quality was a prominent factor on user satisfaction with the system. Lin [1] conducted a study to examine the causes for successful use of online learning systems (OLS) using the updated DeLone and McLean. The results of the study revealed that all three dimensions of the model had a great impact on user satisfaction and actual use of the OLS. However, the Information quality was highlighted as the most significant factor influencing the use/intention to use dimension.

\section{Research Rationale and Goals}

Blended and online learning is attracting the attention of researchers for various reasons, as emergency education exemplified in the one caused by COVID 19 Pandemic (27). The success of such learning depends on the functionalities of the online platform used for this learning. One such platform is Google Classroom. The aim of this research is to investigate the success of Google Classroom in supporting the learning and teaching process in the case of Haneen who used Google Classroom as 
part of a blended learning in her "Automation and Programing" Class. Little literature exists on teachers' point of view regarding the effectiveness for teachers of using Google Classroom as part of a blended learning experience. Hence comes our research to provide a more structured evaluation to the role Google Classroom plays in learning and teaching from a teachers' perspective. For this reason, we have chosen the DeLone and McLean Model of Information Systems Success as a framework for this research. This model enables us to consider various success aspects of the information system, here Google Classroom.

\subsection{Research question}

How is Google Classroom used to support the Learning process in the "Programming and Automation" course?

\section{$4 \quad$ Research Methodology}

For the purpose of this research, the methodology we chose was an exploratory design. Our research fits this design as we are trying to find out how Haneen, the teacher, has used Google Classroom over the past three years to support her teaching process inside the classroom. Our research aims at validating the use of google classroom to support teaching in Hnaeen's case, where one aim of the present research is to generalize the findings of this research on how Google Classroom support the learning process.

\subsection{Context and participants}

An Information technology teacher - Haneen - was the participant in this research as well as two of her students Ayat and Ro'a; these are fictive names. We chose Haneen as she was the only teacher who uses Google Classroom in the Automation and Programming course. This course was only offered for the Information Technology Secondary Stream at the Palestinian schools. This Stream was branched out as a stand-alone secondary school stream in 2017/2018. Because this is new, only two classes are offered for this course in the Tulkarem governorate; one at the boys' school, and the other one at the girls' school. Haneen is the one teacher out of the two who uses Google classroom in her classes. She has been doing so for the past three years. Therefore, we wanted to know more about how Haneen uses Google Classroom for this course to support the teaching process. Hoping that our research will lead to more teachers adopting the idea of using Google Classroom. As for Ayat and Ro'a, we left the choice up for Haneen. So, she chose two students whom she found to have a natural aptitude towards using and understanding technology. 


\subsection{Data collection and analysis tools}

For the purpose of collecting in-depth data from the participants, we opted for using a interviews. The participants were interviewed using semi-structured interview questions. Two of such questions were: What is Google Classroom? What role does Google Classroom play in organizing the course plan?

In order to deeply understand how Google Classroom truly supports the learning process we needed to focus on identifying patterns and themes from the participants' experiences. For this purpose, the data was analyzed using thematic analysis. Braun and Clarke [28] guide for thematic analysis was followed. First, the interviews and the demonstration were transcribed verbatim. Then the transcripts were coded putting emphasis on data that reflected the type of support Google Classroom offers to the learning process inside the classroom, for example, "to support the learning process inside the classroom" and "to create a database for students which they can contribute and add to it." To arrive to the main themes that could answer the research question and make some meaning within the data set, a rigors process of reading, re-reading, preliminary coding and generation of themes and their sub-themes took place. To ensure trustworthiness the analysis and coding of the interviews and demonstration transcripts were first done individually by the three researchers, then the resulting themes were cross-checked and a consensus to common themes was found. Furthermore, once the results were ready, they were sent back to the participants to check for accuracy and resonance with their experiences.

Once themes were produced and fixed, the pattern-matching analytic technique was used to draw relationships and arrive at the results that best provided an answer to our research question. Pattern-matching [28] compares an empirically based patternthat is, one based on the findings from your study - with a predicted one made before data collection. The pattern matching techniques was done against the Updated DeLone and McLean Model of Information Systems (IS) Success presented in the theoretical framework section above.

\section{$5 \quad$ Results}

This section highlights the results of this research, showcased in a pattern that follows the Updated DeLone and McLean Model of Information Systems Success framework.

\subsection{System quality}

The System quality dimension includes the desirable features that an information system should have in order to work, such as ease-of-use. This appeared in two forms in our results, the ease of creating a Google classroom page and the ease of the actual use of the system. The following from Haneen's interview shows how easy it is to start up a Classroom: "I set it [Google Classroom] up at home, you can even do it in 
the class, it only takes two seconds; I just need my Gmail account and I go to the Google Classroom website and click on new."

One of the useful integrations made between Google Classroom and other services is the one with Google Calendar. This link enables students to submit their assignments on time and sends them frequent reminders of how much time they have left until the deadline. Haneen mentioned this as a reason why she does not use Emails for students' assignments submissions: "When I assign students homework, I could give them two days or a week to finish; depending on the nature of the homework itself. It [Google Classroom] shows me how much time is left and it sends students a notification that you have 1 day left or 1 hour till deadline. This is what distinguishes Google Classroom from Email, where reminding students' of the assignment deadline is a lot of hassle."

Another feature that is available at the quality dimension level of Google Classroom is the availability of different file formats inside the app itself, so students can use Google classroom to create different types of files such as documents, slides, and reports: "right within the Google classroom app a student can write her research, also if I asked students to do an excel sheet or a presentation, there is a feature called Google slides [offered by Google Classroom] that they can use. This makes it easier and quicker for students, instead of opening Microsoft PowerPoint and using it, then waiting for it to upload [to Google Classroom]". In the previous excerpt, Haneen emphasizes the convenience of using Google Classroom for task accomplishment. Another aspect of convenience that is offered by Google Classroom is compatibility. Ayat, one of two participating students has shed light on that trait: "It works on both the iOS and Android systems". Furthermore, Ro'a added another feature that "it is free," which is significant for a limited-budget student.

\subsection{Information quality}

The information quality of the IS system is measured by the desirable characteristics of the system outputs. One of the main traits that Haneen has mentioned that could influence the quality of the information presented through Google Classroom is the ability to sequence and organize the presentation of the material in a way that matches the order of the units in the book as well as the intended learning outcomes of the course (ILOs): "So when I organize [on Google Classroom] the units one after the other, I can move it downwards by clicking on 'drag and drop' button and bring to the top the new unit. Hence, the first thing that students encounter when they open the Google Classroom page the new unit." The previous extract focuses on the organizational feature of Google Classroom, which makes presenting the information to the students easier and more organized.

One more feature that could be related to the organizational aspect of the information is the ability to automatically organize and regulate students' assignments submissions. Ayat has referred to this during the interview: "I get a notification on my phone from Gmail or the app itself, I click on the link and get directed to a webpage where I can find all of the details regarding the homework like submission deadline and start date." 
Students know exactly what is required of them in the assignments and when it is due. This also regulates the incoming information from the students to the teacher. Haneen has explained this during the demonstration. Showcasing a previous homework, she said: "I click right here, show assignment, here it lists all the students registered in the class. For example, this student the status of her homework is 'not graded' ye. She completed and submitted the assignment but here it says 'a delayed submission'." She Moved the mouse clicker to other names on the list, saying: "here it say that these students submitted after the deadline was over. While these students have not submitted anything"

Google Classroom offers another feature on the information quality level which appeared of importance to the instructional process is the ability to use various types of materials: "I also do add a lot of instructional material, meaning for example worksheets, or documents containing the material they need to focus on." Having a variety in the types of the resources presented to the students is an important aspect of any eLearning component.

Security is another valuable trait in any IS system. During the observation, Haneen illustrated how Google Classroom offers high levels of security to the course she has created on Google Classroom: "This code [she points out while logging in to Google Classroom] this is the code I give for my students to be able to log in to our Classroom" This trait is confirmed by Ayat: the teacher adds students to the class on Google Classroom through private codes specific to that class."

\subsection{Service quality}

The service quality of the IS system is the support that system users receive from the information systems organization and IT support personnel. Haneen did not address this dimension in elaborate details as she did with the other dimensions. However, she did mention one significant aspect which is privacy. Haneen was pretty concerned with keeping some elements private between the teacher and the students, such as feedback on assignments, to avoid causing embarrassment for the students, as apparent in the following extract: "When the student hands in her homework [via Google Classroom], I can open that homework and I have a section in which I can add a private comment to the students, this protects students' privacy and helps avoid embarrassment." Ayat also confirmed this importance of privacy: "The private comment is usually only between me and the teacher". Ro'a too expressed her valuing of this feature: "The teacher explains where the student's mistake was made [on the assignment] in the private comment between her and the students".

There are many other features that are provided by Google Classroom on the service level that are offered to its users such as a continuous update of their services, lastly done in 2019, and elimination of any errors, if any. Haneen seemed aware of that feature as during the demonstration part of the interview while she was explaining how assignments work on the website, she described that feature as a "newly added one." 


\subsection{Use / Intention to use}

The Use / Intention to use dimension reflects user's actual utilization of the capabilities the IS offers at the System, Service and information levels. The prominent use for Google Classroom is creating a balanced blended learning context through combining an online system with face-to-face classes: "At the school, we have a real classroom and students, so why did we resort to using this Virtual classroom? To support the learning process inside the classroom."

Haneen has talked elaborately about how she employs a number of features Google Classroom offers for the benefit of the course. One of the main ones was creating a database for her students: "That [Google Classroom] will be as a source for students to go back to [She clicks on a topic under the tab titled Educational Material (Database)]." Another feature that Google Classroom offers and Haneen takes advantage of the ability to present her students with a variety of instructional content types: "I also do add a lot of instructional material, meaning for example worksheets, or documents containing the material they need to focus on." During the observation, Haneen has elaborated more on this point by mentioning other types of material that can be added to Google Classroom such as videos and website or webpage links. However, Finding and adding an assortment of appropriate Instructional material is not easy, it takes time and effort.

An additional pronounced use dimension for Google Classroom is assigning students assignments and giving the feedback. During both the interview and the observation Haneen kept coming back to the notion of using Google Classroom as means to provide students with homework. During the demonstration, Haneen has singled out the "Homework tab" as the most important out of the other tabs available. Pointing to one tab out of many on the main page, Haneen says: "out of these we have the most important tab, I use this one a lot with my students, which is homework."

Students cannot be assigned tasks and given homework to do without providing them with some sort of feedback or a grade at the end of it. The following extract from Haneen's interview shows how this could be done easily through Google Classroom: "When it is time to enter students' grades at the middle and end of the semester, this is an important point, we have a tab for Grading and Scoring, this is an important feature for us. Yes, I do want to give students formative feedback, but at the same time I need to grade their work."

\subsection{User satisfaction}

User Satisfaction indicates the level of satisfaction with the IS system. Haneen has expressed her satisfaction with the services Google Classroom offers in different instances. During the interview Haneen has expressed her satisfaction with using Google Classroom in the Automation and Programming course multiple times. She finished the demonstration part of the interview with the following statement that indicates her satisfaction of Google Classroom: "Also, the website [Google Classroom] is full of beneficial features that when it is being at use, the benefits and support it offers to the learning process will get uncovered." 
Additionally, when Haneen was making her point about using Google Classroom to create an archive for her classes, she said that this would "help me and take some work off my hands [in future lesson planning]. Here she is expressing a sense of relief and content. Haneen has also expressed some satisfaction on behalf of her learners when she said that students feel "Happy and satisfied" when they see their feedback and grades on the Google Classroom assignments.

\subsection{NET impact}

NET impact is the extent to which the IS contributes to the success of individuals, groups, organizations, industries, and nations. For example: improved decisionmaking, improved productivity, cost reductions, better retention.

Practice and assignments: One of the most frequently mentioned impacts of using Google Classroom is enhancing students' retention of course material through offering students many opportunities to practice automation and programming skills through using the Google Classroom assignments, as evidenced in Haneen's saying: "We want to reinforce students' kills in Programming, which is not easy at all, mastering these skills requires a lot of practice."

Google Classroom offers students the chance to practice the skills acquired throughout the Automation and Programming course, which is done through the homework feature that Google Classroom offers. This reinforcement of skills cannot be done in class, due to the limited class time allocated to in-class practice and heavy workload: "Writing a code takes time, 40 minutes [class time] is not enough. In 40 minutes, I can only give them the basics in programming and some simple practice activities. At home, we have more time". Ro'a has emphasized this benefit of anytime anywhere when she was asked about what benefits did Google classroom add to the course, she replied": "having enough time to practice writing codes and to program."

Giving students room for discussion is very important as it helps with understanding the material, coming up with new ideas and reinforcing retention of information. Homework is another activity that can be done via Google Classroom to encourage retention: "Did they [students] understand the in class explanation? Did they follow the instructions I have given them for writing codes?"

Another advantage to using online assignments and discussions is encouraging participation, as Ro'a asserted: "I have started to participate more in the class, because the homework I have done and submitted [via Google Classroom], helped me to understand the material well, so when I go to class, I already understand well the concept the teacher is trying to explain, so I am encouraged to participate." In addition, Ayat pointed our attention towards a different but equally important benefit of using google classroom to assign homework, which is increasing learners' accountability: "When "the teacher assigns me homework on google classroom, no, I have to do it because she receives a notification on whether I have submitted or not."

Database and archiving: Haneeni, as already mentioned, uses Google Classroom in an intention to create a database for her students. She expressed how this database could help her students: "This I have noticed more during the Tawjihi exams, how students went back to it [database] and benefited a lot from it." In the previous ex- 
tract, Haneen draws attention to how Google Classroom supports students learning by serving as a database that they can go back to whenever they needed. Having a Database is especially helpful when students have to sit for a high-stakes exam such as the Twajihi.

The other important aspect of material archiving concerns teachers. Haneen talked about how this feature enabled teachers to have a blueprint for their course that they can use to build the same course upon for new groups of students: [opening the main webpage of the Classroom] "as I have mentioned before, this Classroom is the same one from the previous year". Haneen also values the technical features of Google Classroom. Hovering over the symbols Haneen says: "of course here I can add a link for students to benefit from or a file that I have saved on google drive, for students to go back to or work based on it, this is specially used for the study material, video, YouTube."

\section{Discussion}

The present research intended to investigate the success of Google Classroom in supporting the learning and teaching process. To do so, it utilized Delone and Mclean model of information system success. This model enabled to investigate three main components: the quality of the information system, the intention to use the information system, and the impact of this use. Below, we discuss each one of these components as they emerged in the Google Classroom of the participant teacher and her students.

\subsection{Quality of the information system}

The yielded results related to Haneen's Google Classroom, are related first to system quality that center around the ease of use and convenience for both Haneen and her students. For example, the ease of setting up and using a Classroom, preserving student's punctuality, compatibility with different service providers, app-sufficiency and a personalized interface. This comes in line with previous research findings on accessibility, and learning ease being of high importance to the success of the elearning system [29]. The main possible explanation of why these features have contributed to the success of Google Classroom, in the case of Haneen, is the contribution of these features in the success of Haneen to manage the information system. This validates the literature that the system quality being the prominent factor leading to user satisfaction with the system [30]. In addition, Haneen's pointing at the previous features as critical for her experience with the Google Classroom as an information system come in line with Rosita [17] emphasis on the importance of ease of use in Google Classroom to facilitate learning as part of a blended learning context. However, these findings contradict the findings of Azhar and Iqbal [20] on Google Classroom lacking user-friendly interface hence limiting its use. This implies that more research is needed in order to deepen our knowledge about the previous issue. 
The results of the present research are also related to the Information Quality aspect, where the participants indicated the success of this quality that is represented by the characteristics of the system outputs. According to Lin [1], this dimension is evident to have the biggest impact on using the IS system. The most prominent trait mentioned by Haneen was the ability to organize the presentation of the course material in a way that matched the ILOs and the coursebook. This helped in creating an alignment between all elements of the course, consequently bridging the online and face to face component of the blended course very smoothly, as proved by Gerbic [31]. It also created an element of compatibility between the level of online and face to face tasks, which is an important factor in the success of blended learning as perceived by the students [32], as well as for students' satisfaction and making learning more meaningful for them (Herbert, et. al., 2017). Another important feature at this level was the ability to use various types of instructional material, such as videos, worksheets, and documents. Using various instructional tools was found to be an important factor to consider while choosing an online component of the blended learning process [35].

The results of the present research is also related to the service quality, where Haneen and her two students commented positively on the ability of Google Classroom, as an information system, to ensure the privacy of the communication between the teacher and her students. This importance of the service quality, including privacy, is stressed in the literature as component that affects users' perceptions of the information system (e.g., [36-37]).

\subsection{The intention to use/use of the information system}

Haneen expressed her intention to continue using Google Classroom as teacher of the Automation and Programming course. This intention is related to the positive impact of the information system that she used on her teaching and her students' learning side by side to the ease of use of Google classroom as perceived by the teacher. The teacher in our case had the qualifications for e-learning. In addition, the influence of the impact on the intention to use and the actual use in present in the cyclic nature of the DeLone and McLean Model of Information Systems Success. It is also present in other models related to technologies, including information systems, as the Technology Acceptance Model, where the impact is present in the usefulness component.

\subsection{Google classroom impact}

The participants in the present research stressed the positive impact of Google Classroom on the teaching and learning processes. It is worth noting here that one of the main themes that kept recurring throughout the interviews was Supporting the Learning Process; it was traceable in all of the other those other themes and can hardly be isolated from any of them. This is of importance as it could indicate that the overall net impact of using Google Classroom is supporting learning and teaching, which was done in many ways [38]. This impact is related to the different features of 
Google Classroom, as its technical features as its ability to deal with various types of materials This technical aspect serves other semantic aspects as serving students' understanding of the content; i.e., information quality.

The impact of the assessment aspect is also present in the participants' indication of the success of Google Classroom as an information system for learning. Haneen focused on Google Classroom's potentialities for scoring and grading. She considered Google classroom as an important tool to keep track of students' work and scores throughout the semester, so the teacher does not need to manually create a record of students' achievements.

\section{$7 \quad$ Conclusion and Recommendations}

Technology-based blended learning is suggested as a tool for fruitful students' learning, not only as means of communication, but also as a learning environment, for example the one that includes a blend of indoor and outdoor technology-based activities [39]. In the present research, we verified the potentialities of Google Classroom to constitute a supporting platform for the learning processes in an automation and programming course. It proved to satisfy the features of a successful Information System. Thus, it is suggested as a tool that goes together with other tools for supporting meaningful blended learning.

More research is needed to study the impact of technological tools on teachers' instruction and students' learning in the blended context. This need is especially true as the COVID 19 Pandemic showed us the importance of having alternative teaching and learning methods, platforms, and tools to use in case some specific tools became less fruitful for specific educational conditions. Special focus should be given for teacher and students' interaction [40] and students' affect in the learning platforms [29]. It is interesting to study how each feature of the information system influences the learner's affect as a participant in the system.

\section{$8 \quad$ References}

[1] Lin, Q. (2009). Student views of hybrid learning: A one-year exploratory study. Journal of Computing in Teacher Education, 25(2), 57-66. https://doi.org/10.1080/10402454. 2008.10784610

[2] Daher, W., \& Shahbari, A. (2015). Pre-Service teachers' modelling processes through engagement with model eliciting activities with a technological tool. International Journal of Science and Mathematics Education, 13(1), 25-46. https://doi.org/10.1007/s10763-0139464-2

[3] Throne, K. (2003). Blended Learning: How to Integrate Online \& Traditional Learning. London: Kogan Page Limited.

[4] Cronje, J. C., 2020. Towards a New Definition of Blended Learning. The Electronic Journal of eLearning, 18(2), 114-121,

[5] Boelens, R., Van Laer, S., De Wever, B., \& Elen, J. (2015). Blended learning in adult education: towards a definition of blended learning. https://biblio.ugent.be/publication/ 6905076/file/6905079.pdf 
[6] Garrison, D. R. \& Kanuka, H. (2004). Blended learning: Uncovering its transformative potential in higher education. The Internet and Higher Education, 7(2), pp. 95-105. https://doi.org/10.1016/j.iheduc.2004.02.001

[7] Hubbard, R. S. (2015). Student Outcomes and Retention in Online Academic and Training Programs. In J. Keengwe \& J. Agamba (eds.), Models for Improving and Optimizing Online and Blended Learning in Higher Education (pp. 147-172). Hershey, Pennsylvania, USA: IGI Global. https://doi.org/10.4018/978-1-4666-6280-3.ch008

[8] Graham, C.R. (2006). Blended Learning Systems: Definition, Current Trends, and Future Directions. In: Bonk, C.J. and Graham, C.R., Eds., Handbook of Blended Learning: Global Perspectives, Local Designs (pp. 3-21). San Francisco: Pfeiffer Publishing. https://doi.org/ 10.5465/amle.2008.31413871

[9] Bosch, C., Mentz, E., \& Reitsma, G. M. (2019). Integrating Cooperative Learning into the Combined Blended Learning Design Model: Implications for Students' Intrinsic Motivation. International Journal of Mobile and Blended Learning (IJMBL), 11(1), 58-73. https://doi.org/10.4018/ijmbl.2019010105

[10] Stockwell, B. R., Stockwell, M. S., Cennamo, M., \& Jiang, E. (2015). Blended learning improves science education. Cell, 162(5), 933-936. https://doi.org/10.1016/j.cell.2015. $\underline{08.009}$

[11] Delialiouglu, Ö. (2012). Student engagement in blended learning environments with lecture-based and problem-based instructional approaches. Journal of Educational Technology \& Society, 15(3), 310-322.

[12] Means, B., Toyama, Y., Murphy, R., \& Baki, M. (2013). The effectiveness of online and blended learning: A meta-analysis of the empirical literature. Teachers College Record, 115(3), 1-47.

[13] Tong, Y., Kinshuk and Wei, X. (2020). Teaching Design and Practice of a Project-Based Blended Learning Model. International Journal of Mobile and Blended Learning (IJMBL), 12(1), 33-50. https://doi.org/10.4018/ijmbl.2020010103

[14] Wang, J. (2019). Application of blending learning based on network learning space in teaching design of digital art. International Journal of Emerging Technologies in Learning (iJET), 14(03), 177-189. https://doi.org/10.3991/ijet.v14i03.10107

[15] Zhang, L., Wu, Y., Qian, X., Lv, P., \& Zhou, X. (2019). Analysis on WeChat-based blended learning in network marketing course. International Journal of Emerging Technologies in Learning (iJET), 14(17), 86-101. https://doi.org/10.3991/ijet.v14i17.11277

[16] Cristiano, K. L. and Triana, D. A. (2019). Google classroom as a tool-mediated for learning. Journal of Physics: Conference Series, 1161(1). https://doi.org/10.1088/1742$\underline{6596 / 1161 / 1 / 012020}$

[17] Rosita, N. (2019). Google Classroom for Hybrid Learning in Senior High School. Journal of Learning and Teaching in Digital Age, 5(1), 35-41.

[18] Albashtawi, A., \& Al Bataineh, K. (2020). The effectiveness of google classroom among EFL students in jordan: an innovative teaching and learning online platform. International Journal of Emerging Technologies in Learning (iJET), 15(11), 78-88. https://doi.org/10. 3991/ijet.v15i11.12865

[19] Heggart, K. R. and Yoo, J. (2018). Getting the most from google classroom: A pedagogical framework for tertiary educators. Australian Journal of Teacher Education, 43, 140-153. https://doi.org/10.14221/ajte.2018v43n3.9

[20] Azhar, K., \& Iqbal, N. (2018). Effectiveness of Google Classroom: Teachers' Perceptions. Prizren Social Science Journal, 2(2), 52-66. 
[21] Kopeyev, Z., Mubarakov, A., Kultan, J., Aimicheva, G., \& Tuyakov, Y. (2020). Using a Personalized Learning Style and Google Classroom Technology to Bridge the Knowledge Gap on Computer Science. International Journal of Emerging Technologies in Learning (iJET), 15(02), 218-229. https://doi.org/10.3991/ijet.v15i02.11602

[22] DeLone, W. H. and McLean, E. R. (2003). The DeLone and McLean model of information systems success: A ten-year update. Journal of Management Information Systems, 19(4), 9-30. https://doi.org/10.1080/07421222.2003.11045748

[23] Lowry, P. B., Karuga, G. G. and Richardson, V. J. (2007). Assessing Leading Institutions, Faculty, and Articles in Premier Information Systems Research Journals. Communications of the Association for Information Systems, 20. https://doi.org/10.17705/1cais.02016

[24] Urbach, N., \& Mueller, B. (2011). The Updated DeLone and McLean Model of Information Systems Success. In Y. K. Dwivedi, M. Wade, \& S. L. Schneberger (Eds.), Information Systems Theory: Explaining and Predicting Our Digital Society (Vol. 1, pp. 118). (Integrated Series in Information Systems; Vol. 28). New York: Springer. https://doi. org/10.1007/978-1-4419-6108-2_1

[25] DeLone, W. H., \& McLean, E. R. (2016). Information systems success measurement. Foundations and Trends in Information Systems, 2(1), 1-116.

[26] Lwoga, E. (2014). Critical success factors for adoption of web-based learning management systems in Tanzania. International Journal of Education and Development Using ICT, 10(1).

[27] Daher, W., \& Awawdeh Shahbari, J. (2020). Secondary Students' Identities in the Virtual Classroom. Sustainability, 12(11), 4407. https://doi.org/10.3390/su12114407

[28] Braun, V. and Clarke, V. (2006). Using thematic analysis in psychology. Qualitative Research in Psychology, 3(2), 77-101.

[29] Amer, A. and Daher, W. (2019). Moodle quizzes as a teaching tool in English for academic purposes course. International Journal of Innovation and Learning, 25 (1), (1), 35-49. https://doi.org/10.1504/ijil.2019.096513

[30] Cheng, Y. (2012). Effects of quality antecedents on. e-learning acceptance. Internet Research, 22(3), 361-390.

[31] Gerbic, P. (2010). Getting the blend right in new learning environments: A complementary approach to online discussions. Education and Information Technologies, 15(2), 125-137. https://doi.org/10.1007/s10639-009-9100-5

[32] Meyer, S., Wohlers, S. and Marshall, B. (2014). Blended learning: Student experiences. Proceedings of ASCILITE 2014 - Annual Conference of the Australian Society for Computers in Tertiary Education (pp. 89-98).

[33] Herbert, C., Velan, G. M., Pryor, W. M. and Kumar, R. K. (2017). A model for the use of blended learning in large group teaching sessions. BMC Medical Education, 17(1), 197. https://doi.org/10.1186/s12909-017-1057-2

[34] Lowry, P. B., Karuga, G. G. and Richardson, V. J. (2007). Assessing Leading Institutions, Faculty, and Articles in Premier Information Systems Research Journals. Communications of the Association for Information Systems, 20. https://doi.org/10.17705/1cais.02016

[35] Bueno-Alastuey, M. C. and López Pérez, M. V. (2014). Evaluation of a blended learning language course: students' perceptions of appropriateness for the development of skills and language areas. Computer Assisted Language Learning, 27(6), 509-527. https://doi.org/ $\underline{10.1080 / 09588221.2013 .770037}$

[36] Daher, W. (2014). Students' adoption of social networks as environments for learning and teaching: The case of the Facebook. International Journal of Emerging Technologies in Learning, 9 (8), 16-24. https://doi.org/10.3991/ijet.v9i8.3722 
[37] Livingstone, S. (2008). Taking risky opportunities in youthful content creation: teenagers' use of social networking sites for intimacy, privacy and self-expression. New Media \& Society, 10 (3), 393-411. https://doi.org/10.1177/1461444808089415

[38] Bondarenko, O.V., Mantulenko, S.V. and Pikilnyak, A.V. (2018). Google Classroom as a Tool of Support of Blended Learning for Geography Students. In: A.E. Kiv, \& V.N. Soloviev (eds.) Proceedings of the 1st International Workshop on Augmented Reality in Education (pp. 182- 191). Kryvyi Rih, Ukraine: CEUR.

[39] Daher, W., \& Baya'a, N. (2012). Characteristics of middle school students learning actions in outdoor mathematical activities with the cellular phone. Teaching Mathematics and its Applications: An International Journal of the IMA, 31(3), 133-152. https://doi.org/10. 1093/teamat/hrr018

[40] Baya, N., Daher, W., \& Anabousy, A. (2019). The Development of In-Service Mathematics Teachers' Integration of ICT in a Community of Practice: Teaching-in-Context Theory. International Journal of Emerging Technologies in Learning, 14(1), 125-139 https://doi.org/10.3991/ijet.v14i01.9134

\section{Authors}

Maysa Abuzant is a lecturer and $\mathrm{Ph}$. D. student in the faculty of educational sciences at An-Najah National University.

Monji Ghanem and Ayshi Abd-Rabo are Ph.D. students at An-Najah National University.

Wajeeh Daher is a professor doctor in the faculty of educational sciences at AnNajah National University.

Article submitted 2020-09-25. Resubmitted 2021-01-14. Final acceptance 2021-01-15. Final version published as submitted by the authors. 